\title{
Early Jurassic (middle Hettangian) marine gastropods from the Pogibshi Formation (Alaska) and their paleobiogeographical significance
}

\author{
*Mariel Ferrari' ${ }^{1}$, Robert B. Blodgett ${ }^{2}$, Montana S. Hodges ${ }^{3}$, Christopher L. Hodges ${ }^{3}$
}

\author{
I Instituto Patagónico de Geología y Paleontología, IPGP (CCT CONICET-CENPAT), Boulevard Alte. Brown 2915, (9120) Puerto \\ Madryn, Provincia de Chubut, Argentina. \\ mferrari@cenpat-conciet.gob.ar \\ 2 Blodgett and Associates, LLC, 2821 Kingfisher Drive, Anchorage, Alaska 99502, USA. \\ robertbblodgett@gmail.com \\ 3 California State University Sacramento, 6000 J Street, Sacramento, California 95819, USA. \\ montanashodges@gmail.com; christophodges@gmail.com \\ * Corresponding author:mferrari@cenpat-conciet.gob.ar
}

\begin{abstract}
A middle Hettangian marine gastropod assemblage is reported from the Kenai Peninsula of south-central Alaska supplying new paleontological evidence of this group in Lower Jurassic rocks of North America. Pleurotomaria pogibshiensis sp. nov. is described from the middle Hettangian marine succession informally known as Pogibshi formation, being the first occurrence of the genus in the Kenai Peninsula and the oldest occurrence of the genus in present-day Alaska and North America. One species of the genus Lithotrochus, namely Lithotrochus humboldtii (von Buch), is also reported for the first time from the Kenai Peninsula. Lithotrochus has been considered as endemic to South America for a time range from the early Sinemurian to the late Pliensbachian. The newest occurrence of Lithotrochus in rocks of the Pogibshi formation extends the paleobiogeographical and chronostratigraphical distribution of the genus into the present-day Northern Hemisphere. However, the Southern Hemisphere affinities are consistent with the hypothetical interpretations (although supported both by paleobiogeographical and paleomagnetic data) that the Peninsular terrane of south-central Alaska is far-traveled and may have originated at much more southerly paleolatitudes than its presentday position. Two other Early Jurassic caenogastropods typical of the Andean region of South America and of the Tethyan epicontinental seas are described for the first time in the Pogibshi formation, and these are Pseudomelania sp. and Pictavia sp. The new gastropod assemblage reported here shows close affinities with coeval South American and European gastropod faunas, supplying new evidence to interpret their distribution during the Early Jurassic.
\end{abstract}

Keywords: Gastropods, Mid-Hettangian, Pogibshi Formation, Alaska, Taxonomy, Paleobiogeography.

RESUMEN. Significado paleogeográfico de la presencia de gastrópodos marinos en rocas del Jurásico Temprano (Hettangiano medio) de la Formación Pogibshi, Alaska. Una nueva asociación de gastrópodos del Hettangiano medio reconocida en la región sur central de Alaska, aporta nueva evidencia paleontólogica sobre la presencia de este grupo en el Jurásico Inferior de América del Norte. Pleurotomaria pogibshiensis sp. nov. está presente en depósitos marinos del Hettangiano medio de la unidad informalmente conocida como formación Pogibshi, y es la primera ocurrencia del género en la Península Kenai y el registro más antiguo para Alaska y Norte América. Una especie del género Lithotrochus, Lithotrochus humboldtii (von Buch), también se reporta por primera vez en Alaska. Lithotrochus ha sido considerado hasta el momento un género endémico de América del Sur para un intervalo de tiempo, que se extiende desde el Sinemuriano temprano al Pliensbachiano tardío. El nuevo registro de Lithotrochus en rocas de la Formación Pogibshi permite extender su distribución paleobiogeográfica y cronoestratigráfica en el actual hemisferio Norte. Sin embargo, las afinidades con el hemisferio Sur están en consonancia con la interpretación (apoyada por datos paleobiogeográficos y paleomagnéticos) de que el territorio peninsular del centro-sur de Alaska es alóctono y pudo haberse originado en paleolatitudes mucho más al sur que su posición actual. Otros dos caenogastrópodos típicos de la región andina de América del Sur y de los mares epicontinentales del Tethys, tales como Pseudomelania sp. and Pictavia sp., se describen por primera vez para el Jurásico Inferior de la formación Pogibshi. La nueva asociación de gastrópodos aquí descrita muestra estrechas afinidades con faunas coetáneas de América del Sur y Europa, lo que otorga nuevas evidencias para interpretar sus patrones de distribución paleobiogeográfica durante el Jurásico temprano. 


\section{Introduction}

Early Jurassic marine gastropods from the Andean region of South America have been the subject of study by several authors (Bayle and Coquand, 1851; Gottsche, 1878, 1925; Behrendsen, 1891, 1922; Möricke, 1894; Burckhardt, 1900, 1902; Jaworski, 1925, 1926a, b; Weaver, 1931; Feruglio, 1934; Piatnitzky, 1936, 1946; Wahnish, 1942; Gründel, 2001; Damborenea and Ferrari, 2008; Ferrari, 2009, 2011, 2012, 2013, 2014, 2015a, b, 2017; Ferrari et al., 2014, 2015). Ferrari (2009, 2011, 2012, 2013, 2014, 2015a, b, 2017) and Ferrari et al. $(2014,2015)$ have recently supplied new and updated taxonomic information of this group in the Argentinean Jurassic describing several species from the Sinemurian-Toarcian marine deposits of the Neuquén and Chubut basins. Ferrari (2009, 2011, 2014, 2015a, b) also provided qualitative and quantitative paleobiogeographical schemes of gastropod fauna in Argentina in order to interpret the distributional patterns of Mesozoic benthic gastropods along the Andean region of South America.

Jurassic gastropods from North America, however, have received less attention in recent years than their counterparts in South America, and specially the Early Jurassic ones. Sohl (1965) contributed to the taxonomic study of these faunas in North America describing representatives of some families and genera from the Middle Jurassic (Bajocian-Bathonian) of Utah. The author also pointed out that the Alaskan Jurassic sequences may contain a greater diversity of gastropods than other areas in North America, although the difficulty of collecting samples from Alaska limited the basis for evaluating their abundance. Sohl (1965) also argued that the greatest diversity of gastropods in Alaska occurs in the Middle Jurassic (Aalenian-Bathonian) of the Kialagvik Formation and mentioned some gastropod genera (Pleurotomaria, Ambercyclus, Oonia, Cloughtonia and Procerithium) from the Lower Jurassic of the Talkeenta Formation (north of Anchorage); even though few reports have attempted to provide updated taxonomic information and descriptions regarding gastropods from the Early Jurassic of south central Alaska.

Recent studies (Ferrari et al., 2017; Hodges et al., 2018) have supplied new information about Early Jurassic gastropods from the Kenai Peninsula near Seldovia, but without giving detailed taxonomic descriptions. Most of the prior studies have been focused on Paleozoic and Late Triassic gastropod groups (and also on other Jurassic invertebrates such as cephalopods, bivalves, belemnites and brachiopods) (Imlay 1953, 1981, 1982; Lazar et al., 2009, 2015; Sandy and Blodgett, 2009; Dzyuba et al., 2018).

New findings of a middle Hettangian marine gastropod association from the Peninsular terrane of south-central Alaska (Fig. 1) provide new paleontological evidence and supply updated taxonomic information of this group in the Early Jurassic of North America. This new material of middle Hettangian gastropods was collected on July 2, 2016 in the July member of the informal unit known as Pogibshi formation from locality JL198 (Fig. 2). GPS coordinates for the locality are $59.43739^{\circ} \mathrm{N}$ and $151.82033^{\circ} \mathrm{W}$. The fossil bed of this locality extends laterally along the sea cliff for several hundred meters and occurs again around the point at JL199 in a faulted area to the west. This locality is topographically situated in the NW1/4, SW1/4, SW1/4 of section 34, T. 8 S., R. 15 W., Seldovia (B-5) quadrangle map (scale 1:63,360), 1951 edition (minor revisions 1961).

A new Pleurotomaria species, Pleurotomaria pogibshiensis sp. nov., is described here. One species of the genus Lithotrochus is also reported for the first time from the same location and unit/bed(s), and this is Lithotrochus humboldtii (von Buch). Lithotrochus has been considered by Damborenea and Ferrari (2008) as endemic to South America for a time range from the early Sinemurian to the late Pliensbachian. The new occurrence of Lithotrochus extends the paleobiogeographical and chronostratigraphical distribution of the genus into the Northern Hemisphere. Finally, two other Early Jurassic caenogastopods typical of the Andean region of South America and of the Tethyan epicontinental seas are described for the first time from the Pogibshi formation in the Kenai Peninsula. These are Pseudomelania sp. and Pictavia sp.

The new gastropod assemblage reported here from the middle Hettangian marine deposits of the Pogibshi formation shows close affinities with South American and European gastropod faunas supplying new evidence to interpret their paleobiogeographical distribution during the Early Jurassic.

\section{Geologic setting}

The outboard boundary of the Peninsular terrane of southern Alaska is demarked by the Border Range 


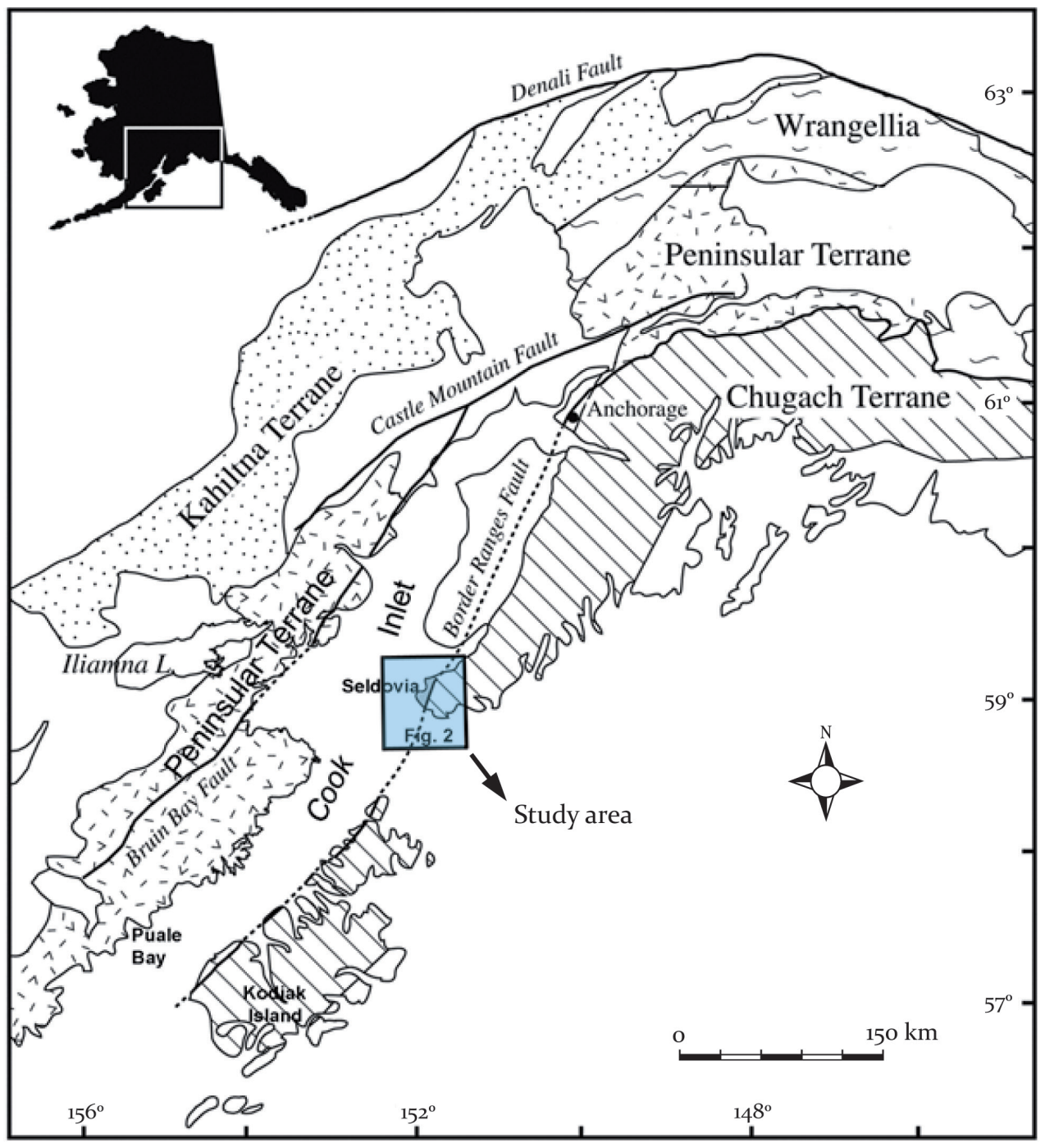

FIG. 1. Terrane map of south-central Alaska showing in gray the sliver of the Peninsular terrane where the Pogibshi formation crops out near Seldovia on the southern Kenai Peninsula (modified from Rioux et al., 2007; Ferrari et al., 2017 and Hodges et al., 2018). See figure 2 for a detailed geologic map of the Seldovia area.

fault system that extends from southwest of Afognak Island to the northeast along the western margin of the Chugach Mountains (Fig. 1). The northeastern limit of the Peninsular terrane occurs in the southern Talkeetna Mountains. Within the Peninsular terrane are the elements of volcanic island arc including prearc rocks, the mainly sedimentary rock sequences of the Upper Triassic Kamishak Formation and the volcanic arc and postarc sedimentary sequences of the Lower Jurassic Talkeetna Formation (Wilson et al., 2012). The boundary between the Kamishak and
Talkeetna Formations had been assumed to be the Triassic-Jurassic but high precision geochronology data indicates the Kamishak continues into the early Hettangian (Pálfy et al., 1999; Barbacka et al., 2006). On the Kenai Peninsula only a sliver of the Peninsular terrane outcrops on the southwestern side of Kachemak Bay southwest of Seldovia (Fig. 2). The sea cliffs in the area contain a fairly well-exposed continuous sequence of Late Triassic to Early Jurassic age deposits (Martin et al., 1915; Martin, 1926; Kelley 1980, 1984). The study area 


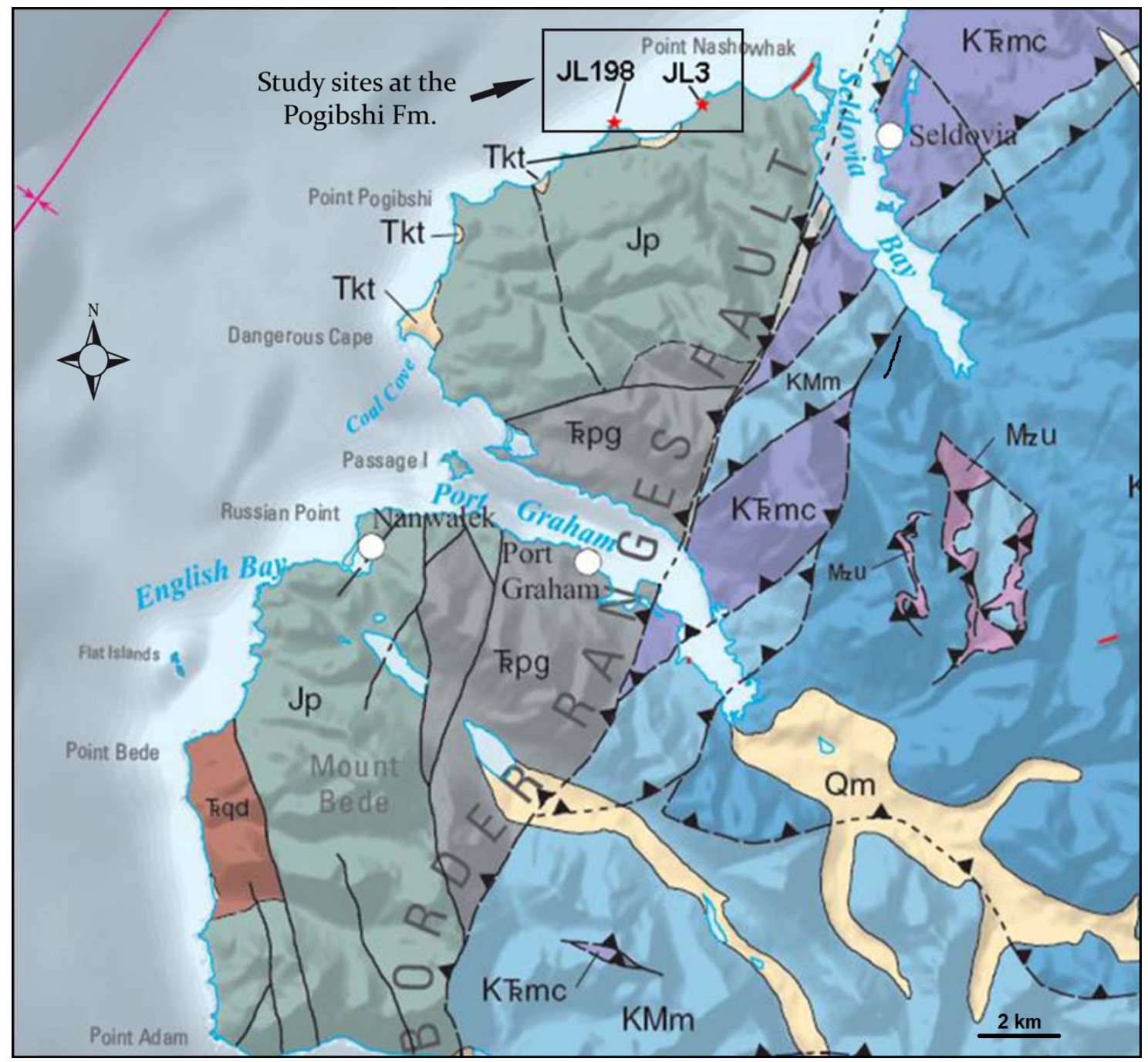

FIG. 2. Geologic map of the Pogibshi formation (Jp) west and southwest of Seldovia Bay. Localities JL198 (= JL199) and JL3 are shown by red stars (modified from Ferrari et al., 2017 and Wilson et al., 2012).

is located in the sea cliffs southwest of Seldovia and has been informally referred to as the Pogibshi formation to distinguish it from the Lower Jurassic Talkeetna Formation. Although the Pogibshi unit has been referred to as a formation it has not been formally named and shows many similarities to the Talkeetna Formation to which some authors have assigned it (Magoon et al., 1976; Bradley et al., 1999). Both the Pogibshi and Talkeetna are of Early Jurassic age and compose thousands of meters of volcanic, volcaniclastic and both marine and nonmarine strata (Martin, 1926; Detterman and Reed, 1980; Draut et al., 2006). The informally defined
Pogibshi formation of Kelley (1980) exposed on the east side of Cook Inlet consists of volcaniclastic rocks interbedded with small amounts of limestone, coal, and tuffaceous argillite. Kelley (1980) divided the unit into three members on the basis of rock type, modal composition, and depositional texture (Fig. 3). The July member consists of dacitic pyroclastic rocks, tuffaceous sandstone, granule conglomerate, and mudstone (Ferrari et al., 2017; Hodges et al., 2018).

Stanton and Martin (1905), Moffitt (1906), Martin (1915, 1916, 1926), Imlay (1981) and Blodgett (2009) reported a diverse Lower Jurassic fauna along the 
coast southwest of Seldovia. Fossils noted in the above cited publications included scleractinian corals, numerous bivalves, gastropods, and ammonites. Blodgett (2009) briefly visited a section of early Sinemurian age, exposed about $3 \mathrm{~km}$ west of Seldovia, and found numerous pectinacean bivalves of the genus Weyla, gastropods, and scleractinian corals.

The bivalve Weyla, an Early Jurassic index fossil, is found primarily along the western coast of North and South America. At least two species of Weyla are present in the July member, one species being middle Hettangian in age and the other being early Sinemurian (Blodgett, personal observation). Early Jurassic ammonites from these same rocks were discussed and, in part, illustrated in Imlay (1981), who recognized both Sinemurian and Hettangian fossil assemblages. The oldest fossils identified within the Pogibshi formation are early Hettangian ammonites (placed here in the mid-Hettangian) found at the base of the July member (Imlay, 1981), suggesting the strong possibility that the lowest member, the Dangerous member may be entirely or in part of Late Triassic age (Ferrari et al., 2017; Hodges et al., 2018). The gastropod genera reported here occur at the JL198 site, in the lower part of the July member (Fig. 3), and are considered here as of mid-Hettangian age (see below).

\section{Age of the gastropod-bearing strata reported here}

Two rock samples from sea cliff exposures of the lower July member were collected for detrital zircon extraction. The upper sample JL3 was collected in a light green-gray tuffaceous volcanic sandstones

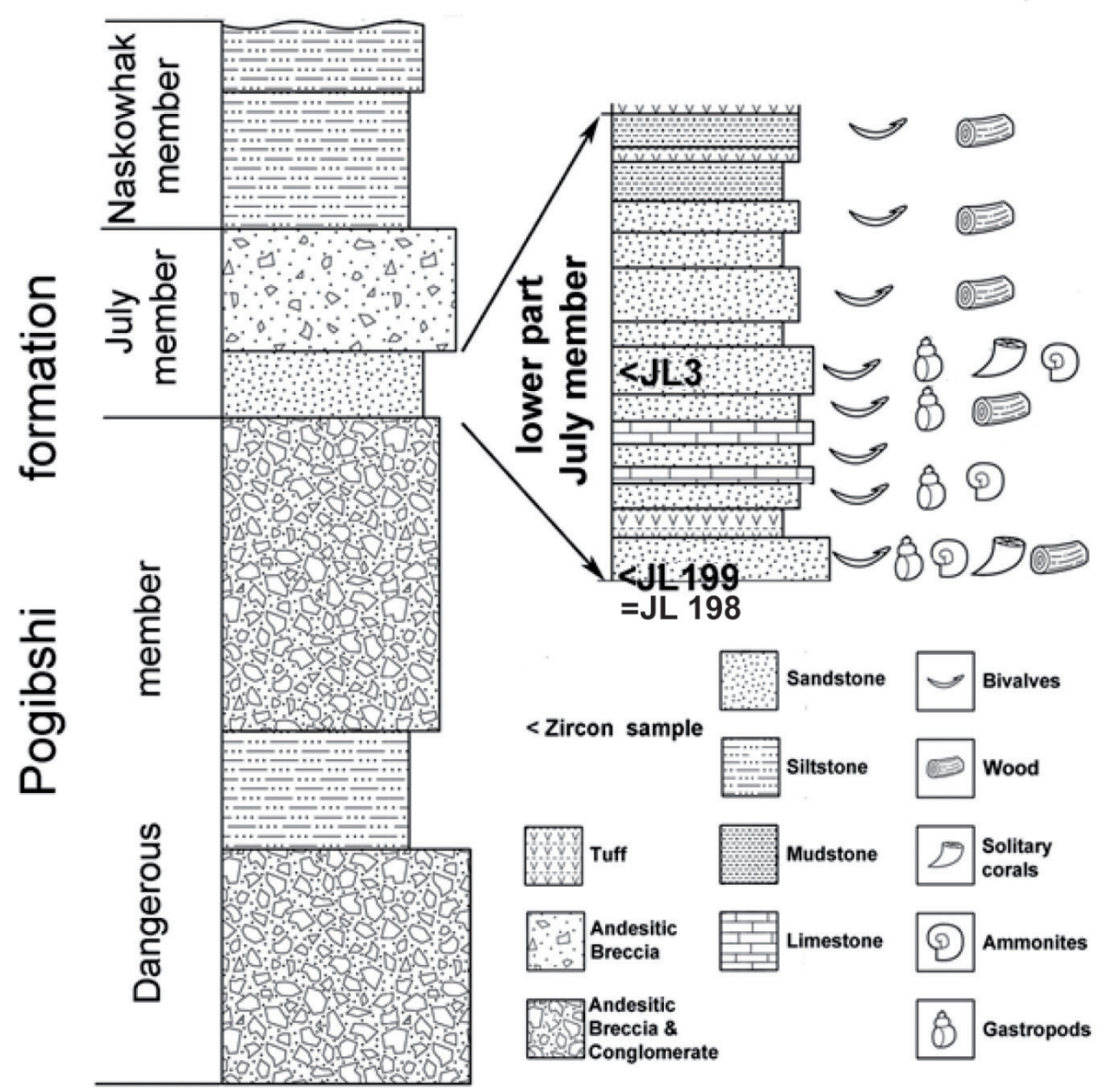

FIG. 3. Stratigraphic composite section of the Pogibshi formation. The position of localities JL198, JL199 and JL3 in the lower part of the July member are indicated (modified from Ferrari et al., 2017 and Hodges et al., 2018). 
interbedded with fossiliferous limy mudstones that contain bivalves, gastropods, ammonites and corals (Fig. 3). This site is well-known for fossiliferous beds and was labeled as 76Jk34 by Kelley (1980) and 31650 by Imlay (1981). The lower sample was collected from Kelley locality 76Jk41 which we designate JL199 at the base of the July member in a tuffaceous volcanic granular red-to-brown conglomerate interbedded with mudstones containing bivalves and occasional corals and ammonites. Other occurrences of the fossil strata at JL199 occur to the east across a fault at JL198 (Fig. 3) and in float material still further east at JL197. The gastropod yielding rocks at JL198 site are considered here as coeval to JL 199 strata and, thus, mid-Hettangian in age. The ages of JL3 and JL199 (=JL198) were confirmed also by comparison to ammonite ages determined by Imlay (1981). Beds near the lower locality (JL199) contain only a single ammonite species identified by Imlay as Psiloceras (Franziceras) cf. P. (F.) ruidum (Buckman), and were assigned an early Hettangian age. Subsequent work by Taylor et al. (2001) suggests that this ammonite interval should instead be considered as the Coronoides zone which is approximately midHettangian (see Taylor et al., 2001). In the beds near JL3 Imlay had previously identified two ammonites, Paracaloceras rursicostatum Frebold and Coroniceras (Paracoroniceras) sp. which indicated an early Sinemurian age. The agreement between the U-Pb $(200.5 \pm 2.5 \pm 1.8 \mathrm{Ma})$ ages and ammonite zonation ages strongly confirms the Hettangian age of the Weyla, corals, and the gastropod fauna described here.

\section{Materials and methods}

The gastropod material described here was collected by Montana Hodges, Christopher Hodges and Robert Blodgett in 2016 during several fieldtrips to the southern Kenai Peninsula near Seldovia, in rocks of the Pogibshi formation, south-central Alaska. Stratigraphical sections for localities yielding gastropods in the Pogibshi formation were described by Ferrari et al. (2017) and Hodges et al. (2018).

The gastropod material is stored in the IPGP (Instituto Patagónico de Geología y Paleontología, CONICET-CENPAT, Puerto Madryn) invertebrate collection (Colección Paleontología de Invertebrados e Icnología, CNP-PIIc) and was prepared by technical staff (Tec. Santiago Bessone) at IPGP laboratory. The specimens were subsequently coated with ammonium chloride to enhance sculpture details for photography. Photographs were taken using a digital camera at IPGP. The systematic classification of the gastropod taxa follows Bouchet et al. (2017).

Institutional abbreviations: IPGP (Instituto Patagónico de Geología y Paleontología), CCT CONICET-CENPAT (Centro Científico Tecnológico, Consejo Nacional de Investigaciones Científicas y Técnicas, Centro Nacional Patagónico).

\section{Systematic paleontology}

\section{Subclass Vetigastropoda Salvini-Pläwen, 1980 \\ Order Trochida (Cox and Knight, 1960a) \\ Superfamily Trochoidea Rafinesque, 1815 \\ Family Trochidae Rafinesque, 1815 Genus Lithotrochus Conrad, 1855}

Type species. Turritella andii d'Orbigny, 1842 (Pleurotomaria humboldtii von Buch, 1839).

Occurrence. Early Jurassic (middle Hettangianlate Pliensbachian); Perú, Chile, Argentina, North America.

Remarks. The genus Lithotrochus has been considered as endemic to South America (see Damborenea and Ferrari, 2008; Ferrari and Bessone, 2015) with its southernmost occurrence in the southwestern region of the Chubut Province, Patagonia Argentina (Ferrari, 2013; Ferrari and Bessone, 2015). The Lithotrochus material reported here provides the first evidence of the genus in the Early Jurassic (mid-Hettangian) strata of North America, extending its paleobiogeographical and chronostratigraphical distribution into the present day Northern Hemisphere.

Lithotrochus humboldtii (von Buch, 1839) (Fig. 4A-Y)

1839 Pleurotomaria humboldtii von Buch: 9, pl. 2, fig. 26.

non 1942 Lithotrochus humboldti (von Buch); Wahnish: 60, pl. 2, fig. 4.

2008 Lithotrochus humboldtii (von Buch); Damborenea and Ferrari: 202, fig. 4.1-4.21, 7.1 (with complete synonymy).

2013 Lithotrochus humboldtii (von Buch); Ferrari: 581, fig. 2 A.

2015 Lithotrochus humboldtii (von Buch); Ferrari and Bessone, p. 353, fig. 3E-H. 


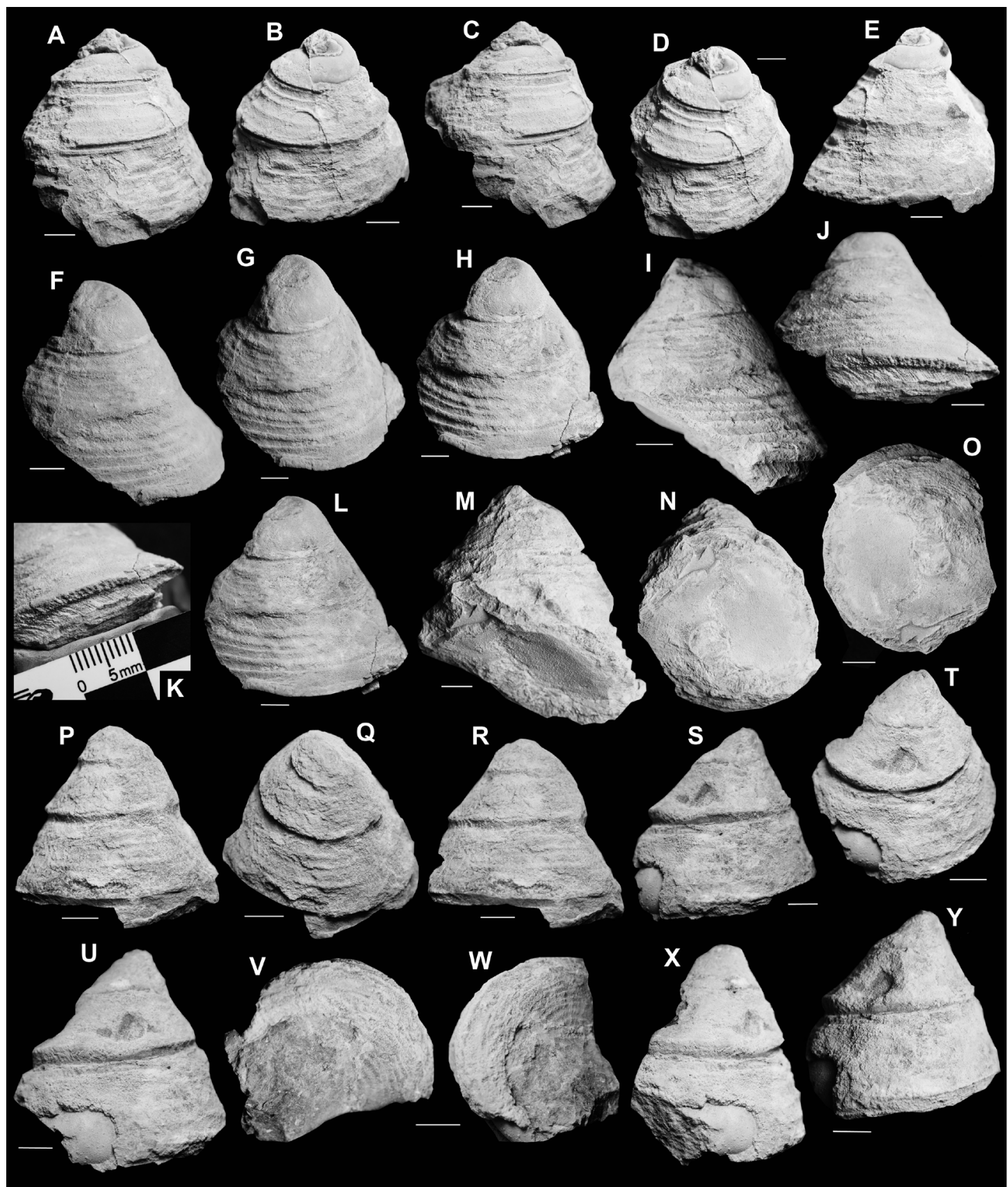

FIG. 4. A-Y. Lithotrochus humboldtii (von Buch, 1839). A-E. CNP-PIIc 0435, lateral views; F-O. CNP-PIIc 0434; F-I, L. Lateral views; J-K. Ornamentation detail of the outer face of last whorl; M-O. Basal and apertural views; P-R. CNP-PIIc 0436; P, R. Lateral views; Q. Apical and lateral view; S-Y. CNP-PIIc 0437; S, U, X, Y. Lateral views; T. Lateral and apical views; $\mathbf{V}$-W. basal view and ornamentation detail. Scale bars $=5 \mathrm{~mm}$.

Material. CNP-PIIc 0434, CNP-PIIc 0435, CNP-PIIc 0436, CNP-PIIc 0437, CNP-PIIc 0438; five replaced teleoconchs, well preserved and complete specimens.
Description. Dextral, anomphalous, conical shell, with trochiform shape on juvenile whorls to cyrtoconoid shape on mature whorls. In the best preserved 
specimens the teleoconch comprises up to 4 whorls. A strong peripheral carina and imbricate whorls are developed on adult growth stages. Suture impressed in a spiral furrow. The shell surface is ornamented by regularly spaced spiral cords intercepted by fine prosocline growth lines. Growth lines strongly prosocline on the outer face of last whorl (Fig. $4 \mathrm{~J}-\mathrm{K}$ ). The base is flattened with spiral ribs intercepted by weak prosocline growth lines. The aperture is holostomatous and subcircular.

Dimensions (mm). CNP-PIIc 0434: height, 40.86*; width, 38.98. CNP-PIIc 0435: height: $36.16^{*}$; width, 34.02. CNP-PIIc 0436: height, $25.30^{*}$; width, 30.42 . CNP-PIIc 0437: height, 30.65*; width, 27.31*. $*=$ measurements taken from fragmentary specimens. Remarks. According to the emended diagnosis proposed by Damborenea and Ferrari (2008, p. 201), the material described here certainly belongs to Lithotrochus humboldtii (von Buch). This is the first record of the species in the Early Jurassic (Hettangian) marine sequences of North America (Alaska), extending its paleobiogeographical and chronostratigraphical distribution into the Northern Hemisphere. Most specimens were found in wellpreserved condition, enabling morphological characterization of the species. For comparisons with other representatives of Lithotrochus humboldtii from the Andean region of South America and with other similar species see Damborenea and Ferrari (2008, p. 204), Ferrari (2013, p. 581), Ferrari (2015a, p. 922), Ferrari and Bessone (2015, p. 353).

Occurrence. Perú, Chile, Argentina (form the early Sinemurian Agassiceras Zone to the late Pliensbachian Fanninoceras Zone); Site JL198, middle Hettangian beds of July member, the Pogibshi formation (Coronoides zone), Seldovia, Alaska (Peninsular terrane, south-central Alaska)

Order Pleurotomariida (Cox and Knight, 1960b) Superfamily Pleurotomarioidea Swainson, 1840 Family Pleurotomariidae Swainson, 1840 Genus Pleurotomaria Defrance, 1826

Type species. Trochus anglicus Sowerby, 1818; Early Jurassic (late Pliensbachian), south-western England, subsequent designation.

Remarks. The systematic position of the type genus Pleurotomaria was recently revised by Monari and Gatto (2013), who proposed a reevaluation of the genus based on seven Pleurotomaria species from the Middle
Jurassic (lower Bajocian) of Luxembourg. They gave a detailed morphological characterization of the genus (see Monari and Gatto, 2013, p. 753). The material described here from the middle Hettangian of North America closely fits their emended diagnosis. The earliest and certain Pleurotomaria species in North America is reported here from middle Hettangian strata of the lower part of the July member of the informally named Pogibshi formation, confirming its paleobiogeographical distibution during the Early Jurassic in the northern Paleo-Pacific region.

\section{Pleurotomaria pogibshiensis sp. nov.} (Fig. 5 A-N)

2017 Pleurotomaria sp.; Ferrari et al., p. 13, fig. 7.

Derivation of name. Referred to the first occurrence of the genus Pleurotomaria in the middle Hettangian of the Pogibshi formation (south-central Alaska), where the material was found.

Type material. Holotype, CNP-PIIc 0439; Paratype, CNP-PIIc 0440; two well preserved and replaced teleoconchs.

Additional material: CNP-PIIc 6000; one incomplete and replaced teleoconch.

Type locality. Site JL198, middle Hettangian beds of July member, Pogibshi Formation (Coronoides zone), Seldovia, Alaska (Peninsular terrane, southcentral Alaska).

Diagnosis. Trochiform and gradate shell; wide ramp; peripheral angulation with a spiral swelling of 20-22 nodes; spiral cords on the shell surface intercepted by prosocline growth lines; broad selenizone at midwhorl with a median spiral cord; base with spiral cords, and opisthocyrt and prosocyrt growth lines; small, rounded nodes on base; umbilicus closed; aperture subcircular to subtrapezoidal.

Description. Dextral, trochiform, medium-sized and moderately low-spired shell. The protoconch is not preserved. The adult shell is gradate and consists of 5 angulate whorls. The whorl ramp is moderately wide, flattened to slightly concave and horizontal, with a maximum width of $3.92 \mathrm{~mm}$ on last whorl. The outer face is sub-vertical on both juvenile and mature teleoconch whorls. The suture is weakly impressed. The peripheral angulation is delimited by a spiral swelling made up of about 20-22 rounded nodes visible on spire whorls. The shell surface is ornamented by regularly spaced spiral cords. 


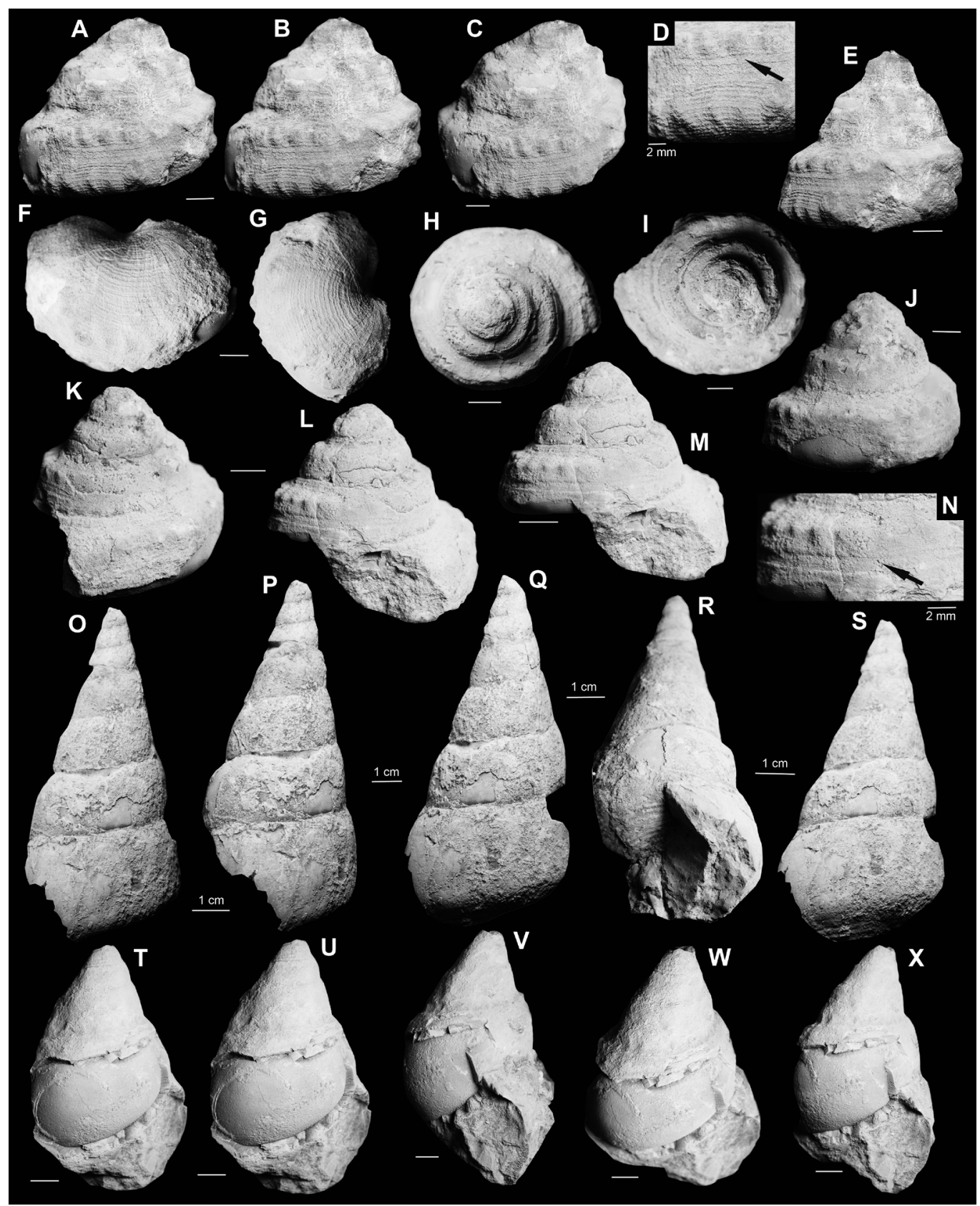

FIG. 5. A-N. Pleurotomaria pogibshiensis sp. nov.; A-G. CNP-PIIc 0440, paratype; A, B, C, E. Lateral views; D. Ornamentation detail on the outer face of last whorl and selenizone (black arrow); F-G. Basal view and ornamentation detail; H-N. CNP-PIIc 0439, holotype; H-I. Apical views; J-K. Lateral views; L-M. Lateral and apertural views; N. Detail of the outer face of last whorl and selenizone (black arrow); O-S. Pseudomelania sp., CNP-PIIc 0441; O, P, Q, S. Lateral views; R. Lateral, basal and apertural views; T-X. Pictavia sp., CNP-PIIc 0442, lateral and apertural views. Scale bars=5 mm, except where otherwise indicated.

The spiral cords are crossed by prosocline to prosocyrt growth lines, giving the ornament a reticulate appearance. The selenizone is broad and developed at mid whorl of the outer face; it is flat and bordered by two sharp spiral cords; a median spiral cord on the selenizone is also visible. Lunulae are 
imperceptible on the selenizone. The base is flat to slightly convex and ornamented by fine and regularly spaced spiral cords which are intersected by opisthocyrt to feebly prosocyrt growth lines. The crossing points of the spiral and collabral elements form small and rounded nodes on the base. The umbilicus is closed or covered by a reflection of the callus of the inner lip. The aperture is subcircular to subtrapezoidal.

Dimensions (mm). Holotype, CNP-PIIc 0440. Height, 38.04; height of the peristome, 11.84*; height of last whorl, 23.88*; width, 37.23; width of the peristome, 21.59.

Paratype, CNP-PIIc 0439. Height, 26.51; height of the peristome, 12.44; height of last whorl, 18.45; width, 30.22; width of the peristome, 14.49*. CNP-PIIc 6000. Height, 14.54*; width, 21.46*. $*=$ measurements taken from fragmentary specimens. Remarks. According to the updated diagnosis of Monari and Gatto (2013), the specimens here described fit the characterization of Pleurotomaria. The type species Pleurotomaria anglica (Sowerby, 1818), from the upper Pliensbachian of England, differs from Pleurotomaria pogibshiensis sp. nov. in having more acute spiral cords on the shell surface, more conspicuous and rounded nodes, and a slightly more gradate shell outline (Monari and Gatto, 2013, p. 756, fig. 3). Two other early Hettangian species are Pleurotomaria cognata Chapuis and Dewalque, 1853, from Belgium and Luxembourg, and Pleurotomaria sp. from Burmerange (south-eastern Luxembourg) (Monari et al., 2011). Pleurotomaria cognata is very similar in shell size and shape to the new species described here, although it differs in having a wide, open and funnel shaped umbilicus, a stronger spiral cord on the outer face of the shell within the selenizone, and more conspicuous and rounded nodes (Monari et al., 2011, p. 365, fig. 11B, C). Pleurotomaria sp. (Monari et al., 2011, p. 366, fig. 11D) has a more coeloconical shell and a subrounded angulation of the whorls. Pleurotomaria wanderbachi Terquem, 1855, from the upper Hettangian of Luxemburg, has a more gradate shell outline than the species described here, has the selenizone running on or slightly above the middle of the outer face, has bulge-shaped adult whorls, and collabral ornament with more densely and regularly spaced threads (Monari et al., 2011, p. 262, fig. 9). Pleurotomaria hettangiensis Terquem, 1855, from the upper Hettangian of Luxemburg, differs from $P$. pogibshiensis sp. nov. in having a less gradate shell and a much narrower whorl ramp, the selenizone running at or slightly below the middle of the outer face and delimited by a sharp spiral line, stronger spiral and nodular elements, and a narrow umbilicus (Monari et al., 2011, p. 263, fig. 10A-D). Pleurotomaria hennocquii Terquem, 1855, also from the upper Hettangian of Luxemburg, differs from $P$. pogibshiensis sp. nov. in having a more cyrtoconical and less gradate shell, less conspicuos and smaller nodes on the peripheral angulation, and the selenizone on adult whorls running below mid whorl (Monari et al., 2011, p. 365, fig. 11A). Pleurotomaria? sp. (in Sohl, 1965, p. 15, pl. 1, figs. 9, 13), from the Middle Jurassic (Bathonian) of Utah, differs from P. pogibshiensis sp. nov. in being broadly umbilicate with no distinct selenizone, in lacking nodes on the whorl ramp, and in having only fine spiral lirae visible on the base.

The earliest Jurassic Pleurotomaria species described so far from the western European epicontinental seas are from the early and late Hettangian (see above). The new pleurotomarid species reported here from the middle Hettangian marine deposits of Seldovia is the earliest report of a Pleurotomaria species in North America.

Four other poorly preserved Pleurotomaria species have been described from the Middle/ Late Jurassic (Bathonian-Portladian) of North America (see Sohl, 1965). For the most part they are based on poor material, but representatives are to be found from west Texas to Alaska in beds of Bathonian to Portlandian age (Sohl, 1965). These are: P. skidegatensis Whiteaves (Yakoun Formation, Vancouver Island, B.C.), P. circumtrunca Cragin (Malone Formation, Texas), Pleurotomaria? borealis Warren (Fernie shale, Canada) and Pleurotomaria cf. $P$. rozete (de Loriol) (Portlandian, East Greenland), however, these species do not retain sufficient character for certain assignment.

Haas (1953) reported a doubtful representative of Pleurotomaria from the Upper Triassic of Perú as Pleurotomaria? aff. haueri Hörnes (in Haas, 1953; p. 30, pl. 2 fig. 1-8); however, following Haas's characterization of the species, it does not seem to be a true representative of the genus. The fragmentary specimen does not show the typical shell morphology and ornament pattern of Pleurotomaria (see Monari and Gatto, 2013); it does not show the broad selenizone running in the middle of the outer face at mid- whorl, and only the presence of a slit 
band on the peripheral keel may refer this species to the Pleurotomariidae.

\section{Subclass Caenogastropoda Cox, 1960 Order Uncertain \\ (according to Bouchet et al., 2017) Superfamily Uncertain \\ (according to Bouchet et al., 2017) \\ Family Pseudomelaniidae R. Hornes, 1884 Genus Pseudomelania Pictet and Campiche, 1862}

Type species. Pseudomelania gresslyi Pictet and Campiche, 1862, by subsequent designation by Wenz (1938); from the Lower Cretaceous (Neocomian) of Switzerland.

Occurrence. Triassic-Cretaceous (Kaim, 2004). Europe, Asia, Africa, Madagascar, New Zealand and America.

\section{Pseudomelania sp.}

(Fig. 5O-S)

Material. CNP-PIIc 0441; one complete and replaced teleoconch.

Description. Dextral, anomphalous, turriculate, high-spired and large-sized shell. The protoconch is not preserved. The teleoconch has a height of $80.94 \mathrm{~mm}$ and a width of $41.76 \mathrm{~mm}$, and comprises seven whorls; the juvenile whorls are flattened to slightly convex and mature whorls become more convex. The spire has a pointed apex and the last teleoconch whorl is more expanded than the spire. Suture is incised. The ornament is poorly developed on the shell surface. A weak angulation delimits the outer face of last whorl. The base is angular to slightly convex and ornamented by regularly spaced spiral striae. The aperture is holostomatous and suboval.

Remarks. Pseudomelania groups high-spired, elongated (pointed spire), not umbilicated, thick shells of simple morphology, usually ornamented with growth lines and with an oval aperture (see Ferrari, 2013; Kaim, 2004). Pseudomelania sp. (Ferrari, 2013, p. 585, fig. 3E), from the Lower Jurassic (upper Pliensbachian-lower Toarcian) of the Andean region of Argentina resembles the Pseudomelania species here described in having regularly spaced spiral striae on the base; however, the North American species is much larger, and has a more acute spire and less incised sutures. Pseudomelania feruglioi Ferrari, 2013 (p. 582, figs. 2F-I, 3A-D; Ferrari, 2017, p. 252, fig. 2.29-37), from the Lower Jurassic (Pliensbachian-Toarcian) of the Andean region of Argentina differs from the North America form in having a more slender shell with the last whorl less expanded, and more flattened whorls with a convex swollen belt in the adapical sutural area. Representatives of Pseudomelania were also reported from the Lower Jurassic (middle Toarcian) of Chile. The species described by Gründel as Pseudomelania sp. 3 (in Gründel, 2001, p. 57, pl. 4, fig. 13-14) differs from Pseudomelania sp. here described in having a slenderer shell, with more concave to flattened whorls, and with a convex swollen belt in the adapical sutural area. Zygopleura (Anoptychya) tilarniocensis Haas, 1953 (p. 125, pl. 7, figs. 44-50, 55, 56) from the Upper Triassic of Perú, is very similar to Pseudomelania sp. here described in shell shape and in its basal ornamentation with spiral cords; however, the species from Perú is smaller, sometimes showing an umbilical niche and collabral growth lines. Pseudomelania? sp. (in Sohl, 1965, p. 21, pl. 3, fig. 7), from the Middle Jurassic (Bathonian) of Utah, is much smaller than the species described here, the whorls are more flattened and the last whorl is slenderer and less expanded.

The species here described is the first occurrence of Pseudomelania in the middle Hettangian of North America.

Occurrence. Site JL198, middle Hettangian beds of July member, Pogibshi formation (Coronoides zone), Seldovia, Alaska (Peninsular terrane, southcentral Alaska).

\section{Grade Architaenioglossa Haller, 1892 (according to Bouchet et al., 2017) Subcohort Campanilimorpha Haszprunar, 1888 (according to Bouchet et al., 2017) Family Ampullinidae Cossmann, 1919 Genus Pictavia Cossmann, 1925}

Type species. Natica pictaviensis d'Orbigny, 1852 (=Natica bajocensis d'Orbigny, 1852) from the Middle Jurassic (Bajocian) of France.

Occurrence. Early Jurassic-Middle Jurassic; Europe, South America.

Remarks. Pictavia shows close resemblance with representatives of the genus Oonia Gemmellaro, 1878; but, members of Pictavia have a narrow ramp which may be smooth or ornamented by spiral rows of fine pits (see Gründel, 2001; Ferrari, 2017). 


\section{Pictavia sp. (Fig, 5T-X)}

Material. CNP-PIIc 0442; one fragmentary teleoconch. Description. Dextral, slightly globose to egg-shaped, medium to large-sized and moderately high-spired shell, with a height of $47.65 \mathrm{~mm}$ and a width of $31.74 \mathrm{~mm}$. The protoconch is not preserved. The teleoconch consists of 4-5 whorls; the spire is acute and has a pointed apex and the last whorl is fragmentary. Spire whorls are flattened to slightly convex becoming more convex in mature growth stages. Last whorl more expanded than spire whorls. Suture is weakly impressed and the sub-sutural ramp is narrowly horizontal. The shell is smooth and prosocline growth lines are not visible. The base is convex and the aperture is oval.

Remarks. The single described specimen represents a member of Pictavia, considering the egg-shaped shell with a narrowly developed sutural ramp as the main diagnostic features. Pictavia rothi Ferrari, 2017 (p. 257, figs. 3.27-3.31, 4.1-4.5), from the Lower Jurassic (Pliensbachian-Toarcian) of the Andean region of Argentina, resembles the species here described in shell shape, although the North American form is larger and has less incised sutures. Oonia sp. indet. (in Gründel, 2001, p. 59, pl. 5 figs. 1-4), from the Lower Jurassic (HettangianPliensbachian) of Chile, is very similar to Pictavia sp., although the species from Chile has more convex whorls and growth lines are visible on the last whorl. Omphaloptycha jaworskii Haas, 1953 (p. 137, pl. 8, figs. 1-28, 31), from the Upper Triassic of Perú, resembles the species from North America; however, $O$. jaworskii is much smaller, growth lines and spiral cords sometimes appear in some specimens, and the sutural ramp is slightly more developed than in Pictavia sp.

The species described here represents the first occurrence of Pictavia in the middle Hettangian of North America.

Occurrence. Site JL198, middle Hettangian beds of July member, Pogibshi formation (Coronoides zone), Seldovia, Alaska (Peninsular terrane, southcentral Alaska).

\section{Paleobiogeography}

The vetigastropod genus Lithotrochus was considered by Damborenea and Ferrari (2008) as endemic of the Andean region of South America, showing a restricted chronostratigraphic distribution in the Early Jurassic from the early Sinemurian to the late Pliensbachian. The species Lithotrochus humboldtii (von Buch, 1839) was one of the first mollusc species reported in the Jurassic of South America in several localities along the Andean region of Perú and Chile, and reaching its southernmost occurrence in the Chubut Province of Argentina (Damborenea and Ferrari, 2008; Ferrari, 2013, 2015a; Ferrari and Bessone, 2015). Lithotrochus rothi Damborenea and Ferrari, 2008 was also reported from the upper Pliensbachian of west-central Argentina (Damborenea and Ferrari, 2008; Ferrari, 2015), also found southernmost in coeval deposits of the Chubut Province (Ferrari, 2013). The newest occurrence of Lithotrochus humboldtii in middle Hettangian marine deposits of the Peninsular terrane (Alaska) refutes the idea that Lithotrochus is endemic of South America and extends its paleobiogeographical distribution into strata found now in the present-day Northern Hemisphere. Additionally, the record of these species in Seldovia (Alaska) extends the chronostratigraphic distribution of the genus to the earliest Jurassic (middle Hettangian). This suggests a possible origin of Lithotrochus in the present-day south-central Alaska during the middle Hettangian, becoming a component of the benthic marine communities in the Early Jurassic in North and South America after the Late Triassic mass extinction event. However, as noted elsewhere, the exact position of the Peninsular terrane during the Hettangian is still up for debate, but it was probably situated at a more southerly position, possibly as far south as northern South America. One of us (Blodgett) has earlier speculated that the Peninsular terrane and associated southern Alaskan terranes were probably situated off the western coast of the Americas, possibly as far as northern South America during the Late Triassic/ Early Jurassic (see also Weems and Blodgett (1996) for further speculation on the rapid northerly motion evidenced by the Peninsular terrane during the Jurassic). Though the Peninsular terrane evidenced globally significant northward motion during the Jurassic, it seems to have docked more or less into its present-day northern Boreal position by the Late Jurassic (Weems and Blodgett, 1996; Blodgett, 2012; Blodgett et al., 2015).

Ferrari (2015) interpreted the Late Triassic/Early Jurassic faunal turnover after the Late Triassic crisis in 
South America and established a paleobiogeographical scheme for the gastropod fauna across the Perúvian Paleo-Pacific seaway. Here we provide the first approach to interpret the relationships and connections of the different records of one of the most common Early Jurassic gastropod genera in South America, Lithotrochus, after the Late Triassic crisis.

Lithotrochus follows a distribution pattern and migration routes along the Americas during the Early Jurassic very similar to that of the coeval bivalve genus Weyla (see Damborenea and Manceñido, 1979; Damborenea, 2011; Hodges et al., 2018). Thus, the Paleo-Pacific seaway may have been the most plausible mechanism for biotic exchange of Lithotrochus from the Peninsular terrane during the middle Hettangian to the Andean region of South America during the Sinemurian-Pliensbachian (Fig. 6A).

The vetigastropod genus Pleurotomaria shows a wide chronostratigraphic distribution from the Middle Triassic to the Recent and is found all over the world. Begg and Grant-Mackie (2003) supported the idea of an origin of Pleurotomaria in the late Anisian-Ladinian (Mid-Triassic) in the southwestern Pacific sea. In the European epicontinental seas, Pleurotomaria first appeared during the early Hettangian and reached a widespread distribution in the European region through dispersal along the southern Tethyan margin (Monari and Gatto, 2013). The Late Triassic?- Early Jurassic radiation of Pleurotomaria from the western Tethys to North and South America may be related to the opening of a mid-Atlantic seaway, the Hispanic Corridor. According to Blodgett and Frýda (2001) and Frýda and Blodgett (2003) the strong similarities between western North American Late Triassic gastropods with those of the western Tethys suggests that the Hispanic Corridor may have been open as early as the Norian. However, Porter et al. (2013) provided evidence by Os isotope data that connectivity between the Eastern Pacific and Tethyan oceans initiated during the latest Sinemurian. The earliest -although doubtful- occurrence of Pleurotomaria in the Western Hemisphere dates from the Late Triassic (Norian-Rhaetian) of Perú (Haas, 1953; as Pleurotomaria? aff. haueri). However, following the characterization of Haas (1953), the Perúvian form does not seem to be a true representative of Pleurotomaria. The oldest certain record of the genus in the Americas is reported here from the middle Hettangian of south-central Alaska. Most probably the genus became widespread across the Paleo-Pacific seaway to the Andean region of South America as early as the Sinemurian. Gründel (2001) and Ferrari (2014) mentioned some Pleurotomaria species from the lower Sinemurian of northern Chile and from the upper Pliensbachian-lower Toarcian of central and south western Argentina. Ferrari and Damborenea (2015) also reported a representative of Pleurotomaria in the lower Bajocian of Argentina, coinciding with a time span of maximum species radiation (see Monari and Gatto, 2013).

\section{Conclusions}

The new gastropod assemblage from the southwestern Seldovia region (Alaska) reported here supply new taxonomic and palaeobiogeographical evidence of this taxa in the very Early Jurassic of North America, showing also close affinities with coeval South American and European gastropod faunas. These records have elements in common with the Andean associations in the Southern Hemisphere. Thus, this can help to infer ancient marine connections between both areas during the Early Jurassic.

Based on the general shell morphology with a gradate shape and angulated outer edge of the ramp, broad selenizone, strongly prosocyrt nodular elements and spiral ornament dominant on adult shell, our middle Hettangian Pleurotomaria, Pleurotomaria pogibshiensis sp. nov., represents a new species and its stratigraphic occurrence suggest it is the earliest species of the genus reported in present-day North America. The new findings reported here from just one locality in the Peninsular terrane of southern Alaska, manifest that new localities of North American Jurassic gastropods may greatly extend our knowledge and stimulate further research in the future, facilitating new taxonomic information and appropriate interpretation of the palaeobiogeographical distribution of marine gastropods in North America during the Jurassic.

\section{Acknowledgments}

We thank S. Bessone for preparation of the specimens at the IPGP laboratory, and M. de los Á. Meza for her help in the location of the gastropods specimens in the IPGP repository (CNP-PIIc). We are also grateful to an anonymous reviewer for the valuable comments. 

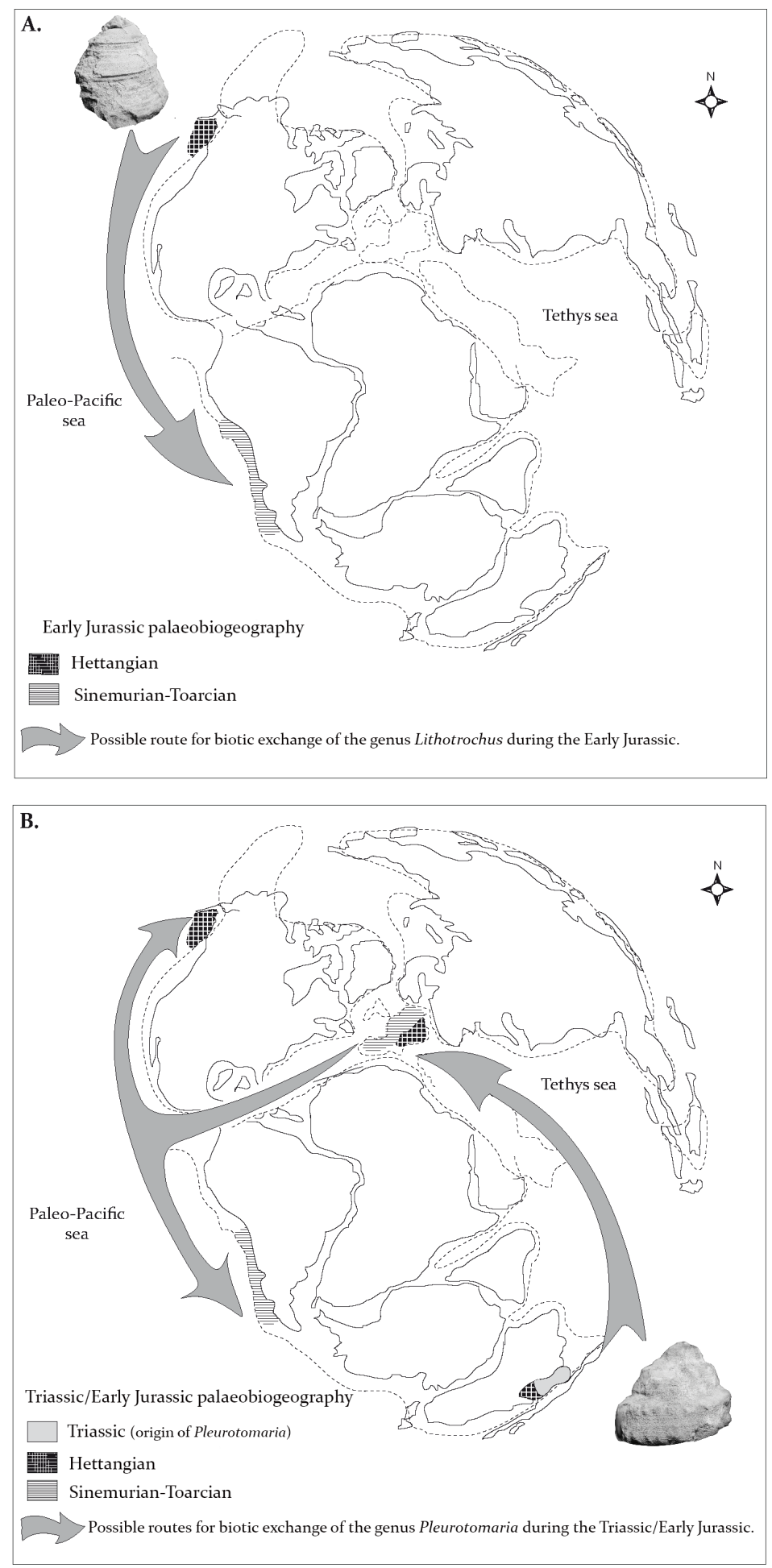

FIG. 6. Map showing the paleogeographic distribution of the genera Lithotrochus and Pleurotomaria here reported during the Late Triassic/Early Jurassic. A. Possible route for biotic exchange of the genus Lithotrochus during the Early Jurassic. B. Possible routes for biotic exchange of the genus Pleurotomaria during the Triassic/Early Jurassic. 


\section{References}

Barbacka, M.; Pálfy, J.; Smith, P.L. 2006. Hettangian (Early Jurassic) plant fossils from Puale Bay (Peninsular terrane, Alaska). Review of Palaeobotany and Palynology 142: 33-46.

Bayle, E.; Coquand, H. 1851. Mémoire sur les Fossiles recueillis dans le Chili par M. Ignace Domeyko et sur les terrains auxquels ils appartiennent. Mémoires de la Societé Géologique de France 2 (4): 1-47.

Begg, J.G.; Grant-Mackie, J.A. 2003. New Zealand and New Caledonian Triassic Pleurotomariidae (Gastropoda, Mollusca). Journal of the Royal Society of New Zealand 33: 223-268.

Behrendsen, O. 1891. Zur Geologie des Ostabhanges der argentinischen Cordillere. Teil I. Zeitschrift der Deutschen Geologischen Gesellschaft 43: 369-420.

Behrendsen, O. 1922. Contribución a la geología de la pendiente oriental de la Cordillera Argentina. Academia Nacional de Ciencias, Actas 7: 157-227, Córdoba.

Blodgett, R.B. 2009, Report on day trip (5/16/07) to visit Mesozoic rocks exposed in Port Graham and near Seldovia, southern Kenai Peninsula. In Preliminary results of recent geologic investigations in the HomerKachemak Bay area, Cook Inlet basin (LePain, D.L.; editor). Progress during the 2006-2007 field season: Alaska Division of Geological and Geophysical Surveys Preliminary Interpretive Report 2009-8C: 109-116.

Blodgett, R.B. 2012. The bivalve genus Retroceramus Koshelkina, 1959. Alaska Geology-Newsletter of the Alaska Geological Society 42 (8): 5-8.

Blodgett. R.B.; Frýda, J. 2001. Upper Triassic gastropod biogeography of western North America. Geological Society of America, Abstracts with Programs 33 (3): p. A-53.

Blodgett, R.B.; Hults, C.P.; Stromquist, L.; Santucci, V.L.; Tweet, J.S. 2015. An inventory of Middle Jurassic fossils and their stratigraphic setting at Fossil Point, Tuxedni Bay, Lake Clark National Park and Preserve, Alaska: National Park Service Natural Resource Report NPS/LACL/NRR-2015/932. National Park Service, Fort Collins: 158 p. Colorado.

Bouchet, P.; Rocroi, J.-P.; Hausdorf, B.; Kaim, A.; Kano, Y.; Nützel, A.; Parkhaev, P.; Schrödl, M.; Strong, E. 2017. Revised classification, nomenclator and typification of gastropod and monoplacophoran families. Malaocologia 61 (1-2): 1-495.

Bradley, D.C.; Kusky, T.M.; Haeussler, P.J.; Karl, S.M.; Donley, D.T. 1999. Geologic map of the Seldovia quadrangle, scale 1:250000. United States Geological Survey Open File Report 99-18: 1 p.

Buch, L. von. 1839. Pétrifications recueillies en Amérique par Mr. Alexandre de Humboldt et par Mr. Charles Degenhardt. Imprimerie de l'Académie Royale des Sciences: 22 p. Berlin.

Burckhardt, C. 1900. Profils géologiques transversaux de la Cordillčre Argentino Chilienne. Stratigraphie et tectonique. Anales del Museo de La Plata, Sección Geología y Mineralogía 2: 1-136.

Burckhardt, C. 1902. Le Lias de la Piedra Pintada (Neuquén). III. Sur les fossiles marines du Lias de la Piedra Pintada, avec quelques considérations sur l'âge et l'importance du gisement. Revista del Museo de La Plata 10: 243-249.

Chapuis, M.F.; Dewalque, M.G. 1853. Description des fossiles des terrains secondaires de la province de Luxembourg. Mémoires couronnés et Mémoires des savants étrangers, Académie Royale de Belgique 25: 1-302.

Conrad, T.A. 1855. Remarks on the fossil shells from Chile, collected by Lieutenant Gillis, with descriptions of the species. In United States Naval Astronomical Expedition to the southern hemisphere, during the years 1849-'50'51-'52 (Gillis, J.M.; editor). Supplementary Papers A.O.P. Nicholson 2: 282-286. Washington.

Cossmann, M. 1925. Essais de Paléonconchologie comparée, Treizième livraison. Les Presses Universitaires de France 13: 345 p. Paris.

Cossmann, M.; Peyrot, A. 1919. Conchologie néogénique de l'Aquitaine, tome III. Actes de la Société Linnéenne de Bordeaux 70: 181.356.

Cox, L.R. 1960. Thoughts on the classification of the Gastropoda. Proceedings of the Malacological Society of London 33: 239-261.

Cox, L.R.; Knight, J.B. 1960a. Suborder Trochina Cox and Knight, 1960. In Treatise on Invertebrate Paleontology, Part I, Mollusca 1 (Moore, R.C.; editor). Lawrence, Geological Society of America and University of Kansas Press: 237 p.

Cox, L.R; Knight, J.B. 1960b. Suborder Pleurotomariina Cox and Knight, 1960. In Treatise on Invertebrate Paleontology, Part I, Mollusca 1 (Moore, R.C.; editor). Geological Society of America and University of Kansas Press: 197 p. Lawrence.

Damborenea, S. 2011. Paleobiogeografía de bivalvos marinos jurásicos. Annales de la Academia Nacional de Ciencias: 26 p. Buenos Aires.

Damborenea, S.E.; Manceñido, M.O. 1979. On the palaeogeographical distribution of the pectinid genus Weyla (Bivalvia, Lower Jurassic). Palaeogeogr Palaeoclimatol Palaeoecol 27: 85-102. 
Damborenea, S.E.; Ferrari, S.M. 2008. El género Lithotrochus Conrad (Gastropoda, Vetigastropoda) en el Jurásico temprano de Argentina. Ameghiniana 45: 197-209.

Defrance, M.J.L. 1826. Dictionnaire des Sciences Naturelles 39. F.G. Levrault, Éditeur à Strasbourg: 534 p.

Detterman, R.L.; Reed, B.L. 1980. Stratigraphy, structure, and economic geology of the Iliamna Quadrangle, Alaska. United States Geological Survey Bulletin 1368-B: B1-B86. 1 sheet, scale 1:250,000.

D’Orbigny, A . 1842-1843. Paléontologie française. Description des mollusques et rayonnés fossiles. Terrains crétacés, tome 2, gastéropodes. Victor Masson 4: 456 p. Paris.

D’Orbigny, A. 1850-1860. Paléontologie française. Terrain Jurassique, tome 2, gastéropodes. Victor Manson: 622 p. Paris.

Draut, A.E.; Clift, P.D.; Blodgett, R.B. 2006. Field-trip guide to volcanic and volcaniclastic deposits of the Lower Jurassic Talkeetna Formation, Sheep Mountain, south-central Alaska. U.S. Geological Survey, OpenFile Report 2006-1124: 21 p.

Dzyuba, O.S.; Schraer, C.D.; Hults, C.P.; Blodgett, R.B.; Schraer, D.J. 2018. Early Bajocian belemnites of Southcentral Alaska: new data and new perspectives on mid-Middle Jurassic Megateuthididae and Belemnopseidae biogeography. Journal of Systematic Palaeontology 17 (11): 911-935.

Ferrari, S.M. 2009. Cosmopolitan Early Jurassic marine gastropods from westcentral Patagonia, Argentina. Acta Palaeontologica Polonica 54: 449-461.

Ferrari, S.M. 2011. Early Jurassic Ataphridae (Mollusca: Gastropoda) from Chubut, Argentina: paleogeographic and paleoecologic implications. Ameghiniana 48 (1): 63-77.

Ferrari, S.M. 2012. The genera Cryptaulax and Procerithium (Procerithiidae, Caenogastropoda) in the Early Jurassic of Patagonia, Argentina. Alcheringa 36: 323-336.

Ferrari, S.M. 2013. New Early Jurassic gastropods from west-central Patagonia, Argentina. Acta Palaeontologica Polonica 58 (3): 579-593.

Ferrari, S.M. 2014. Patellogastropod and Vetigastopoda (Mollusca, Gastropoda) from the marine Jurassic of Patagonia, Argentina. Historical Biology 26 (5): 563-581.

Ferrari, S.M. 2015a. Early Jurassic marine gastropods from Argentina: a palaeobiogeographical analysis based on Vetigastropoda. Journal of Systematic Palaeontology 13: 919-941.

Ferrari, S.M. 2015b. Systematic revision of Late Triassic marine gastropods from Central Perú: considerations on the Late Triassic/Early Jurassic faunal turnover. Andean Geology 42 (1): 71-96. doi: 10.5027/andgeoV42n1-a05.
Ferrari, S.M. 2017. Early Jurassic Caenogastropoda and Architectibranchia from the Neuquén Basin, Argentina. Journal of Paleontology 91 (2): 245-264.

Ferrari, S.M.; Bessone, S. 2015. A new Early Jurassic marine locality from southwestern Chubut Basin, Argentina. Andean Geology 42 (3): 349-363. doi: 10.5027/andgeoV42n3-a04.

Ferrari, S.M.; Damborenea, S.E. 2015. Early Bajocian marine gastropods from the Neuquén Basin, Argentina. Ameghiniana 52: 625-646.

Ferrari, S.M.; Kaim, A.; Damborenea, S.E. 2014. The genera Calliotropis Seguenza and Ambercyclus n. gen.: (Vetigastropoda, Eucyclidae) from the Early Jurassic of Argentina. Journal of Paleontology 88 (6): 1174-1188.

Ferrari, S.M.; Damborenea, S.E.; Manceñido, M.O.; Griffin, M. 2015. Early Jurassic Trochotomidae (Vetigastopoda, Pleurotomarioidea) from the Neuquén Basin, Argentina. Journal of Paleontology 89 (2): 331-345. doi: 10.1017/ jpa.2014.28..

Ferrari, M.; Blodgett, R.B.; Hodges, M.S.; Hodges, C.L. 2017. The oldest representative (Early Jurassic, middle Hettangian) of the gastropod genus Pleurotomaria in North America (Discovered in the Pogibshi formation near Seldovia, Kenai Peninsula, Alaska). Alaska Geology, Newsletter of the Alaska Geological Society 47 (9): 7-15.

Feruglio, E. 1934. Fossili Liassici della Valle del Rio Genua (Patagonia). Giornale di Geologia, Annali del Reale Museo Geologico di Bologna 9: 1-64.

Frýda, J.; Blodgett, R.B. 2003. Silberlingiella, a new purpurinid genus (Littorinoidea, Gastropoda) from the Late Middle Norian (Late Triassic) of the Clan Alpine Range, western Nevada. Mitteilungen des Geologisch-Paläontologischen, Instituts der Universität Hamburg 87: 47-54.

Gehrels, G.; Dickinson, W.; Ross, G.; Stewart, J.; Howell, D. 1995. Detrital zircon reference for Cambrian to Triassic miogeoclinal strata of western North America. Geology 23: 831-834.

Gemmellaro, G.G. 1874. Sopra i fossili della zona con Terebratula Aspasia Menegh. della provincia di Palermo e di Trapani. Giornale di Scienze Naturali ed Economiche di Palermo 10: 1-73.

Gottsche, C. 1878. Ueber jurassische Versteinerungen aus der argentinischen Cordillere. Palaeontographica 3: 1-50.

Gottsche, C. 1925. Contribuciones a la Paleontología de la República Argentina. Sobre fósiles jurásicos de la Cordillera Argentina (Paso del Espinacito, prov. de San Juan). Actas Academia Nacional de Ciencias 8: 229-283. Córdoba. 
Gründel, J. 2001. Gastropoden aus dem Jura der südamerikanischen Anden. Freiberger Forschungshefte C492: 43-84.

Haas, O. 1953. Mesozoic Invertebrate Faunas of Perú. Bulletin of the American Museum of Natural History 101: 1-328.

Haller, B. 1892. Die Morphologie der Prosobranchier. Morphologisches Jahrbuch 18: 451-543.

Haszprunar, G. 1988. On the origin and evolution of major gastropod groups, with special reference to the Streptoneura. Journal of Molluscan Studies 54: 367-441.

Hodges, M.; Hodges, C.; Blodgett, R.; Stanley, G., Jr.; Ferrari, M. 2018. Hettangian marine invertebrates from the Kenai Peninsula near Seldovia, Alaska. New Mexico Museum of Natural History and Science, Bulletin 80: 5-15.

Hörnes, R. 1884. Elemente der Palaeontologie (Palaeozoologie). Verlag Von Veit and Comp: 594 p. Leipzig. doi: 10.5962/bhl.title.14950.

Imlay, R.W. 1953. Callovian (Jurassic) ammonites from the United States and Alaska Part 2. Alaska Peninsula and Cook Inlet regions. United States Geological Survey Professional Paper 249-B: 41-108.

Imlay, R.W. 1981. Early Jurassic ammonites from Alaska, Alaska. U.S. Geological Survey, Professional Paper 1148: 49 p.

Imlay, R.W. 1982. Late Bajocian Ammonites From Southern Alaska. U.S. Geological Survey, Professional Paper 1189: 42 p.

Jaworski, E. 1925. Contribución a la paleontología del Jurásico Sudamericano. Publicación de la Dirección General de Minería, Geología e Hidrología, sección Geología 4: 1-160.

Jaworski, E. 1926a. La fauna del Lias y Dogger de la Cordillera Argentina en la parte meridional de la provincia de Mendoza. Academia Nacional de Ciencias, Actas 9: 137-316. Córdoba.

Jaworski, E. 1926b. Lias und Dogger. Teil 1. In Beiträge zur Paläontologie und Stratigraphie des Lias, Doggers, Tithons und der Unterkreide in den Kordilleren im Süden der Provinz Mendoza (Argentinien) (Jaworski, E.; Krantz, F.; Gerth, H.; editors). Geologische Rundschau 17a: 373-427. Berlin.

Kaim, A. 2004. The evolution of conch ontogeny in Mesozoic open sea gastropods. Palaeontologia Polonica 62: 3-183.

Kelley, J.S. 1980. Environments of deposition and petrography of lower Jurassic volcaniclastic rocks, southwestern Kenai Peninsula, Alaska. University of California, Davis, Ph.D. dissertation: 304 p.
Kelley, J.S.1984. Geologic map and sections of the southwestern Kenai Peninsula west of Port Graham, Alaska: U.S. Geological Survey, Open-File Report 84-162, 1 sheet scale 1:63,360.

Lazar, I.; Sandy, M.R.; Blodgett, R.B. 2009. Early Jurassic (Pliensbachian) bivalve and brachiopod fauna from the Peninsular Terrane, southern Talkeetna Mountains, Alaska-paleobiogeographic signatures and tectonic significance. Geological Society of America, Abstracts with Programs 41 (5): 27-28.

Lazar, I.; Sandy, M.R.; Blodgett, R.B. 2015. Paleobiogeographic signature and tectonic significance of Early Jurassic (Pliensbachian) bivalve and brachiopod fauna from the Peninsular terrane, southern Talkeetna Mountains, Alaska. Geological Society of America, Abstracts with Programs 47 (4): p. 20.

Magoon, L.B.; Adkison, W.L.; Egbert, R.M. 1976. Map showing geology, wildcat wells, Tertiary plant fossil localities, K-Ar age dates, and petroleum operations, Cook Inlet area, Alaska. U.S. Geological Survey Map I-1019, 3 sheets scale 1:250,000.

Martin, G.C. 1915. The western part of the Kenai Peninsula. In Geology and mineral resources of Kenai Peninsula, Alaska (Martin, G.C.; Johnson, B.L.; Grant; editors). U.S. Geological Survey, Bulletin 587: 41-111.

Martin, G.C. 1916. Triassic rocks of Alaska. Geological Society of America Bulletin 27: 685-718.

Martin, G.C. 1926. The Mesozoic stratigraphy of Alaska. U.S. Geological Survey, Bulletin 776: 493 p.

Martin, G.C.; Johnson, B.L.; Grant, U.S. 1915. Geology and mineral resources of the Kenai Peninsula, Alaska. U.S. Geological Survey, Bulletin 587: 243 p.

Moffit, F.H. 1906. Gold fields of the Turnagain Arm region. U.S. Geological Survey, Bulletin 277: 7-52.

Monari, S.; Gatto, R. 2013. Pleurotomaria Defrance, 1826 (Gastropoda, Mollusca) from the Lower Bajocian (Middle Jurassic) sediments of Luxemburg, with considerations on its systematics, evolution and palaeobiogeographical history. Palaeontology 56: 751-781.

Monari, S.; Valentini, M.; Conti, A. 2011. Earliest Jurassic patellogastropod, vetigastropod, and neritimorph gastropods from Luxembourg with considerations on the Triassic-Jurassic faunal turnover. Acta Paleontológica Polonica 56: 349-384.

Möricke, W. 1894. Versteinerungen des Lias und Unteroolith von Chile. Neues Jahrbuch für Mineralogie, Geologie und Paläontologie, BeilageBand 9: 1100.

Pálfy, J.; Smith, P.L.; Mortensen, J.K.; Friedman, R.M. 1999. Integrated ammonite biochronology and $\mathrm{U}-\mathrm{Pb}$ geochronometry from a basal Jurassic section in 
Alaska. Geological Society of America Bulletin 111 (10): 1537-1549.

Piatnitzky, A. 1936. Estudio geológico de la región de los Ríos Chubut y Genua. Boletín de Informaciones Petroleras 13: 83-118.

Piatnitzky, A. 1946. Relaciones estratigráficas de la región del Río Chubut. Boletín de Informaciones Petroleras 23: 173-178.

Pictet, F.J.; Campiche, G. 1861-1864. Description des fossiles du terrain Crétacé des environs de Sainte-Croix. In Matériaux pour la Paléontologie Suisse (Pictet F.J.; editor) $2: 1-752$.

Porter, S.J.; Selby, D.; Suzuki, K.; Gröcke, D. 2013. Opening of a trans-Pangaean marine corridor during the Early Jurassic: Insights from osmium isotopes across the Sinemurian-Pliensbachian GSSP, Robin Hood's Bay, UK. Palaeogeography, Palaeoclimatology, Palaeoecology 375: 50-58.

Rafinesque, C.S. 1815. Analyse de la nature, ou tableau de Punivers et des corps organises. Privately published: 224 p. Palermo.

Rioux, M.; Hacker, B.; Mattinson, J.; Kelemen, P.; Blusztajn, J.; Gehrels, G. 2007. Magmatic development of an intra-oceanic arc: High-precision $\mathrm{U}-\mathrm{Pb}$ zircon and whole-rock isotopic analyses from the accreted Talkeetna arc, south-central Alaska. Geological Society of America Bulletin 119: 1168-1184.

Salvini-Plawen, L.V. 1980. A reconsideration of systematics in the Mollusca (phylogeny and higher classification). Malacologia 19: 249-278.

Sandy, M.R.; Blodgett, R. 2009. A review of Mesozoic brachiopods as paleogeographic, paleoecological, and tectonic tools in terrane analysis in the Western Cordilleran of North America (in particular Alaska and British Columbia. In annual Meeting Cordilleran Section, No. 105. University of British Columbia, Okanagan Kelowna, British Columbia 15-1: 34 p.

Sohl, N.F. 1965. Marine Jurassic Gastropods, Central and Southern Utah. Contributions to Paleontology. U.S. Geological Survey, Professional Paper: 48 p.
Stanton, T.W.; Martin, G.C. 1905. Mesozoic section on Cook Inlet and Alaska Peninsula. Geological Society of America Bulletin 16: 391-410.

Sowerby J. 1812-1822. The mineral conchology of Great Britain. Benjamin Meredith: 765 p. London.

Swainson, W. 1840. A treatise on malacology or shells and shell-fish. Longman: 499 p. London.

Taylor, D.G.; Guex, J.; Rakus, M. 2001. Hettangian and Sinemurian ammonoid zonation for the Western Cordillera of North America. Bulletin de la Société Vaudoise des Sciences Naturelles 87 (4): 381-421.

Terquem, O. 1855. Paléontologie de l'étage inferieur de la formation liassique de la province de Luxembourg, Grand-Duché (Hollande) et de Hettange, du department de la Moselle. Mémoires de la Société Géologique de France 5: 219-343.

Wahnish, E. 1942. Observaciones geológicas en el Oeste del Chubut. Estratigrafía y fauna del Liásico en los alrededores del rio Genua. Boletín del Servicio Geológico Nacional 51: 1-73. Buenos Aires.

Weaver, C. 1931. Paleontology of the Jurassic and Cretaceous of West Central Argentina. Memoirs of the University of Washington 1: 1-469.

Weems, R.E.; Blodgett, R.B. 1996. The pliosaurid Megalneusaurus: A newly recognized occurrence in the Upper Jurassic Naknek Formation of the Alaska Peninsula. In Geologic Studies in Alaska by the U.S. Geological Survey, 1994. U.S. Geological Survey Bulletin 2152: 169-176.

Wenz, W. 1938-44. Gastropoda. Prosobranchia. In Handbuch der Paläozoologie, Band 6 (Schindewolf, O.H.; editor). Verlag Gebrüder Bornträger: 1639 p. Berlin.

Wilson, F.H.; Hults, C.P.; Schmoll, H.R.; Haeussler, P.J.; Schmidt, J.M.; Yehle, L.A.; Labay, K.A. 2012. Geology of the Cook Inlet region, Alaska, including parts of the Talkeetna, Talkeetna Mountains, Tyonek, Anchorage, Lake Clark, Kenai, Seward, Iliamna, Seldovia, Mount Katmai, and Afognak 1:250,000-scale quadrangles. U.S. Geological Survey Scientific Investigations Map SIM-3153, pamphlet: 71 p., 2 sheets scale 1:250,000.

Manuscript received: June 25, 2019; revised/accepted: December 10, 2019; available online: May 29, 2020. 